\title{
Pengembangan Media Pembelajaran Variasi Permainan Senam Lantai Berbasis Aplikasi Articulate Storyline
}

\author{
Amelia Nada Agustin*, Ari Wibowo Kurniawan \\ Universitas Negeri Malang, Jl. Semarang No. 5 Malang, Jawa Timur, Indonesia \\ *Penulis korespondensi, Surel: amelianadaagustin@gmail.com
}

Paper received: 24-5-2021; revised: 14-6-2021; accepted: 21-6-2021

\begin{abstract}
So far, the learning process of floor gymnastics is done through games. However, it has never been done using learning media for eating, there needs to be development and research related to learning media that package material variations of floor exercise in an interesting manner and the data is carried out during the online learning process. The development method refers to the method proposed by Lee and Owens. The results of the development trial involved 25 teachers of KKG PJOK Elementary School, Wagir District, Malang Regency. The results showed that the product can be categorized as valid with the percentage in small group trials of 74.76 percent and 79.17 percent of the results of large group trials.
\end{abstract}

Keywords: media; floor exercise; games; articulate storyline

\begin{abstract}
Abstrak
Proses pembelajaran senam lantai selama ini dilakukan melalui permainan. Namun belum pernah dilakukan menggunakan media pembelajaran makan perlu adanya pengembangan dan penelitian terkait media pembelajaran yang mengemas materi variasi permainan senam lantai secara menarik dan data dilakukan saat proses pembelajaran daring. Metode pengembangan mengacu metode yang dikemukakan oleh Lee dan Owens. Hasil uji coba pengembangan melibatkan sebanyak 25 guru KKG PJOK Sekolah Dasar Kecamatan Wagir Kabupaten Malang. Hasil penelitian menunjukan bahwa produk dapat dikategorikan valid dengan persentase pada uji coba kelompok kecil sebesar 74,76 persen dan 79,17 persen hasil uji coba kelompok besar.
\end{abstract}

Kata kunci: media; senam lantai; permainan; articulate storyline

\section{Pendahuluan}

Pendidikan merupakan interaksi antara faktor-faktor yang terlibat di dalamnya guna mencapai tujuan pendidikan. Interaksi faktor-faktor tersebut secara jelas dapat tersaksi dalam proses belajar, yaitu ketika pendidik mengajarkan nilai-nilai, ilmu, dan keterampilan pada peserta didik, sementara peserta didik menerima pengajaran tersebut. Sasaran proses pendidikan tidak sekedar pengembangan intelektualitas peserta didik dengan memasok pengetahuan sebanyak mungkin, lebih dari itu, pendidikan merupakan proses pemberian pengertian, pemahaman, dan penghayatan sampai pada pengamalan yang diketahuinya.

Pendidikan Jasmani merupakan bagian integral dari sistem pendidikan secara keseluruhan, yang memfokuskan pengembangan aspek kebugaran jasmani, keterampilan gerak, keterampilan berpikir kritis, stabilitas emosional, keterampilan sosial, penalaran dan tindakan moral melalui aktivitas jasmani. Pendidikan jasmani anak sekolah dasar sebagaimana telah tertera dalam kurikulum pendidikan jasmani sekolah dasar di atas, maka di dalam intensifikasi penyelenggaraan pendidikan sebagai suatu proses pembinaan manusia yang berlangsung seumur hidup, peranan Pendidikan Jasmani adalah sangat penting, yaitu 
memberikan kesempatan pada siswa untuk terlibat langsung dalam aneka pengalaman belajar melalui aktivitas jasmani yang dilakukan secara sistematis. Alif \& Sudirjo (2019), menyatakan bahwa pendidikan jasmani merupakan suatu proses pembelajaran melalui aktivitas jasmani yang didesain untuk meningkatkan kebugaran jasmani serta mengembangkan keterampilan motorik, sikap sportif, dan kecerdasan yang lebih baik dari segi fisik, mental, dan emosional, dengan adanya pendidikan jasmani kondisi jasmani dan rohani peserta didik diharapkan menjadi lebih baik.

Media pembelajaran yang digunakan oleh peneliti berupa aplikasi yaitu aplikasi Articulate Storyline. Articulate Storyline adalah sebuah software atau perangkat lunak yang memiliki fungsi sebagai media dalam pembelajaran interaktif. Software ini dapat digunakan dalam mempresentasikan informasi sesuai dengan tujuannya. Dengan menggunakan Articulate Storyline tampilan presentasi akan jauh lebih menarik sehingga para peserta yang mengikuti presentasi tersebut akan lebih mudah untuk memahami dan terhindar dari rasa bosan (Pratama 2018). Jadi aplikasi articulate storyline ini lebih menarik digunakan sebagai media pembelajaran karena telah terdapat berbagai jenis dalam bentuk yang diinginkan seperti gambar, teks, video, audio dan sebagainya, dengan aplikasi tersebut sangat memungkinkan bahwa siswa akan lebih tertarik dan meningkatkan daya serap saat proses pembelajaran berlangsung.

Telah terdapat beberapa materi pada mata pelajaran PJOK yang diajarkan di kelas IV SD, salah satunya adalah senam lantai. Materi senam lantai umumnya kurang diminati siswa, dikarenakan pengajaran yang monoton sehingga siswa cepat merasa bosan. Hal tersebut dapat memicu peserta didik tidak menerima pembelajaran dengan baik. Pada tahap ini sebagian besar anak didik lebih menyukai proses pembelajaran yang lebih banyak mengandung unsur permainan. Permainan adalah kegiatan yang dirancang untuk mengembangkan kemampuan seseorang untuk menjadikan proses belajar menarik agar siswa melakukan pembelajaran dengan mudah dan rasa senang. Stimulasi yang dilakukan terhadap perkembangan kognitif ini dilakukan melalui bermain dan permainan (Tatminingsih 2019). Permainan atau game sekarang sudah menjadi umum dipakai untuk pekan olahraga atau pesta olahraga seperti “Olympic Game", asian Game” (Bangun 2016).

Seiring berkembangnya zaman dan teknologi yang semakin modern, maka teknologi bisa dijadikan alat untuk kegiatan sehari-hari, bahkan untuk proses pembelajaran khususnya di saat pembelajaran daring seperti saat ini. Untuk menunjang permainan-permainan agar lebih menarik dalam proses pembelajaran, maka variasi permainan dikemas dalam di dalam aplikasi bernama Articulate Storyline yang telah dijelaskan oleh peneliti. Dengan adanya media pembelajaran berupa aplikasi ini akan membantu guru dalam proses pembelajaran daring, selain itu siswa juga akan tertarik saat materi senam lantai diajarkan karena di dalam aplikasi juga disajikan gambar, video, musik yang akan membuat siswa antusias mengikuti dan menerima pembelajaran materi senam lantai.

Peneliti menggunakan subjek KKG PJOK SD Kecamatan Wagir Kabupaten Malang untuk melakukan penelitian guna menyelesaikan syarat mata kuliah skripsi. Dengan jumlah subjek sebanyak 25 orang guru PJOK SD dilakukan analisis kebutuhan dengan menyebarkan angket pada tanggal 15 Juni 2020 melalui google formulir, maka diperoleh hasil yaitu pada pertanyaan tentang pemberian materi senam lantai kepada peserta didik kelas IV di SD Kecamatan Wagir yaitu $100 \%$ menjawab memberi materi senam lantai, lalu pada pertanyaan tentang materi 
senam lantai diajarkan setiap tahun yaitu 100\% menjawab materi senam lantai diajarkan setiap tahunnya di SD Kecamatan Wagir, kemudian pada pertanyaan nomor 3 tentang apakah siswa antusias ketika Bapak atau Ibu guru mengajarkan materi senam lantai yaitu 94,1\% menjawab antusias dan 5,9\% menjawab tidak antusias. Lalu pada pertanyaan nomor 4 yaitu tentang apakah Bapak atau Ibu guru mengajarkan materi senam lantai melalui permainan yaitu 70,6\% menjawab melakukan materi senam lantai melalui permainan dan 29,4\% menjawab tidak melakukan materi senam lantai melalui permainan, kemudian pada pertanyaan nomor 5 tentang pada situasi pandemi COVID-19 ini apakah Bapak atau Ibu Guru melakukan proses pembelajaran daring materi senam lantai yaitu 58,8\% menjawab melakukan proses pembelajaran secara daring dan $41,2 \%$ menjawab tidak melakukan proses pembelajaran secara daring.

Lalu pada pertanyaan nomor 6 tentang penggunaan aplikasi dalam proses pembelajaran senam lantai yaitu 47,1\% menjawab menggunakan aplikasi dan 52,9\% menjawab tidak menggunakan aplikasi, kemudian pada pertanyaan nomor 7 tentang apakah menggunakan aplikasi articulate storyline yaitu ada 29,4\% menjawab menggunakan aplikasi articulate storyline dan 70,6\% menjawab tidak menggunakan aplikasi articulate storyline. Pada pertanyaan nomor 8 apakah pendidik pernah menggunakan aplikasi articulate storyline yaitu 88,2\% menjawab belum pernah menggunakan aplikasi articulate storyline dan 11,8\% menjawab menggunakan aplikasi articulate storyline, kemudian pada pertanyaan nomor 9 tentang dengan adanya aplikasi dalam proses pembelajaran gerak lokomotor dan non lokomotor senam lantai dapat mempermudah dalam menyampaikan materi pembelajaran yaitu $82,4 \%$ menjawab dapat mempermudah dalam proses pembelajaran, terakhir pada pertanyaan nomor 10 yaitu apakah Bapak/Ibu guru setuju apabila diadakan penelitian pengembangan media pembelajaran aplikasi tentang variasi permainan gerak lokomotor dan non-lokomotor senam lantai untuk KKG PJOK Sekolah Dasar Kelas IV di Kecamatan Wagir Kabupaten Malang yaitu 100\% Bapak dan Ibu Guru PJOK di SD Kecamatan Wagir Kabupaten Malang menerima diadakannya penelitian pengembangan media pembelajaran aplikasi tentang variasi permainan senam lantai untuk KKG PJOK Sekolah Dasar Kelas IV di Kecamatan Wagir Kabupaten Malang.

Sedangkan hasil wawancara yang dilakukan kepada ketua KKG PJOK SD Kecamatan Wagir didapatkan hasil bahwa selama daring pembelajaran hanya dilakukan melalui Whatsapp saja, dan dirasa kurang efektif, oleh karena itu guru-guru membutuhkan media pembelajaran yang tepat dan menarik, selain itu siswa juga antusias jika diberikan materi senam lantai melalui permainan, tentunya permainan-permainan yang baru juga akan membuat siswa tertarik dan antusias dalam menerima materi, karena terkadang permainan yang umum dan sering dilakukan membuat mereka kurang antusias, serta terkadang saat materi senam lantai siswa diajak ke lapangan terbuka untuk umum, lalu siswa dibebaskan untuk bersenam lantai karena variasi-variasi permainan yang baru dirasa kurang.

Dengan adanya masalah yang sudah ada dan sudah dibahas sebelumnya peneliti memecahkan masalah tersebut dengan cara mengembangkan media pembelajaran aplikasi tentang variasi permainan senam lantai untuk KKG PJOK sekolah dasar kelas IV di Kecamatan Wagir Kabupaten Malang. Variasi permainan ini terdapat 5 macam permainan yang dirancang dan difokuskan pada materi gerak lokomotor yaitu senam lantai yang dikemas dalam sebuah aplikasi yang bisa digunakan untuk pembelajaran khususnya pada saat daring. Berdasarkan latar belakang peneliti tertarik untuk melakukan penelitian dan pengembangan yang berjudul 
"Pengembangan Media Pembelajaran Variasi Permainan Senam lantai Berbasis Aplikasi Articulate Storyline Untuk KKG PJOK Sekolah Dasar Kelas IV di Kecamatan Wagir Kabupaten Malang".

Tujuan penelitian ini adalah untuk mengembangkan sebuah produk berupa aplikasi yang dapat digunakan sebagai media pembelajaran yang berisi variasi permainan senam lantai untuk mengatasi beberapa masalah dalam pembelajaran PJOK khususnya pada saat pembelajaran daring yang dikarenakan oleh adanya pandemi virus covid-19.

\section{Metode}

Dalam pengembangan media pembelajaran materi senam lantai berbasis aplikasi articulate storyline ini, peneliti menggunakan model prosedural. Model prosedural adalah model yang bersifat deskriptif, yaitu menggariskan langkah-langkah yang harus diikuti untuk menghasilkan produk. Penelitian dan pengembangan ini mengacu pada model pengembangan Research \& Development $(R \& D)$ menggunakan model pengembangan untuk multimedia yang dikembangkan oleh Lee \& Owen (2004). Tahap-tahap dari penelitian ini antara lain adalah analisis, desain, pengembangan, implementasi, dan evaluasi. Tahap analisis meliputi need assessment dan front-end analysis. Kegiatan yang dilakukan dalam front-end analysis antara lain audience analysis, technology analysis, media analysis dan extant-data analysis. Alasan kenapa menggunakan model pengembangan dari Lee \& Owen (2004) ini karena pengembangan ini berbasis komputer yaitu multimedia interaktif. Instrumen skala likert mempunyai tingkatan jawaban yang meliputi sangat positif sampai sangat negatif. Untuk keperluan analisis data kuantitatif jawaban dapat diberi skor yang sudah ditetapkan yaitu satu (1), dua (2), tiga (3) dan empat (4), guna keperluan analisis kuantitatif. Skala likert (Sugiyono, 2015) dapat dilihat pada tabel berikut:

\section{Tabel 1. Skala Penilaian Pernyataan Positif}

\begin{tabular}{clcc}
\hline No. & \multicolumn{1}{c}{ Keterangan } & Jawaban & Skor Positif \\
\hline 1. & Sangat Setuju & A & 4 \\
2. & Setuju & B & 3 \\
3. & Ragu-ragu & C & 2 \\
4. & Tidak Setuju & D & 1 \\
\hline
\end{tabular}

Rumus yang digunakan dalam mengolah data dalam bentuk analisis deskriptif kuantitatif persentase, sebagai berikut:

$V=\frac{T S E V}{S-\max } \times 100 \%$

\section{Keterangan:}

$\mathrm{V} \quad$ : Validitas

TSEV : Total skor empirik validator

S-max : Skor maksimal yang diharapkan

100\% : Bilangan konstanta

Selanjutnya agar memudahkan pada perolehan ketepatan data hasil analisis persentase, maka diklasifikasikan dengan rentangan persentase perolehan yang didapatkan. Menurut (Irawan \& Japarianto, 2013) dalam jurnalnya, klasifikasi persentase berikut ini: 
Tabel 2. Kriteria dan Parameter Kualitas Produk

\begin{tabular}{ccc}
\hline Kriteria & Keterangan & Makna \\
\hline $75,01 \%-100,00 \%$ & Sangat Valid & Digunakan tanpa revisi \\
$50,01 \%-75,00 \%$ & Cukup Valid & Digunakan dengan revisi kecil \\
$25,01 \%-50,00 \%$ & Tidak Valid & Tidak dapat digunakan \\
$00,00 \%-25,00 \%$ & Sangat Tidak Valid & Terlarang digunakan \\
\hline
\end{tabular}

\section{Hasil dan Pembahasan}

\subsection{Hasil}

Data yang dipaparkan pada bahasan ini meliputi data: 1) validasi ahli PJOK, 2) validasi ahli pembelajaran, 3) validasi ahli permainan SD, 4) validasi ahli media, 5) validasi ahli senam lantai, 6) uji coba kelompok kecil, 7) uji coba kelompok besar.

Tabel 3. Hasil Analisis Data Ahli Pendidikan Jasmani, Olahraga dan Kesehatan

\begin{tabular}{clcc}
\hline No & \multicolumn{1}{c}{ Aspek } & Kelayakan & Kategori \\
\hline 1 & Kesesuaian & $75 \%$ & Cukup Valid \\
2 & Kejelasan & $75 \%$ & Cukup Valid \\
3 & Kemudahan & $75 \%$ & Cukup Valid \\
4 & Ketepatan & $75 \%$ & Cukup Valid \\
5 & Keefektifan & $75 \%$ & Cukup Valid \\
& Rata-rata & $75 \%$ & Cukup Valid \\
\hline
\end{tabular}

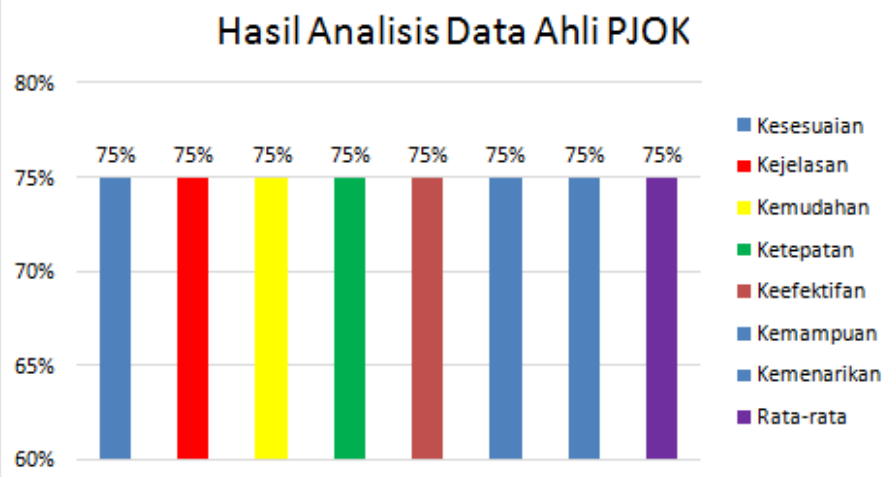

Gambar 1. Diagram Persentase Penilaian Ahli PJOK pada Produk Pengembangan Media Pembelajaran Aplikasi Variasi Permainan Senam Lantai

Berdasarkan hasil analisis data yang diperoleh dari ahli PJOK dengan persentase sebesar $75 \%$, hasil tersebut didapatkan berdasarkan aspek-aspek tertentu kemudian dikonversikan berdasarakan tabel klasifikasi kelayakan menunjukan bahwa produk pengembangan media pembelajaran variasi permainansenam lantai telah memenuhi kriteria cukup valid dan layak digunakan. 
Tabel 4. Hasil Analisis Data Ahli Pembelajaran

\begin{tabular}{clcl}
\hline No & \multicolumn{1}{c}{ Aspek } & Kelayakan & Kategori \\
\hline 1 & Kesesuaian & $91.70 \%$ & Sangat Valid \\
2 & Kejelasan & $91.20 \%$ & Sangat Valid \\
3 & Kemudahan & $83.30 \%$ & Sangat Valid \\
4 & Ketepatan & $100 \%$ & Sangat Valid \\
& Rata-rata & $91.50 \%$ & Sangat Valid \\
\hline
\end{tabular}

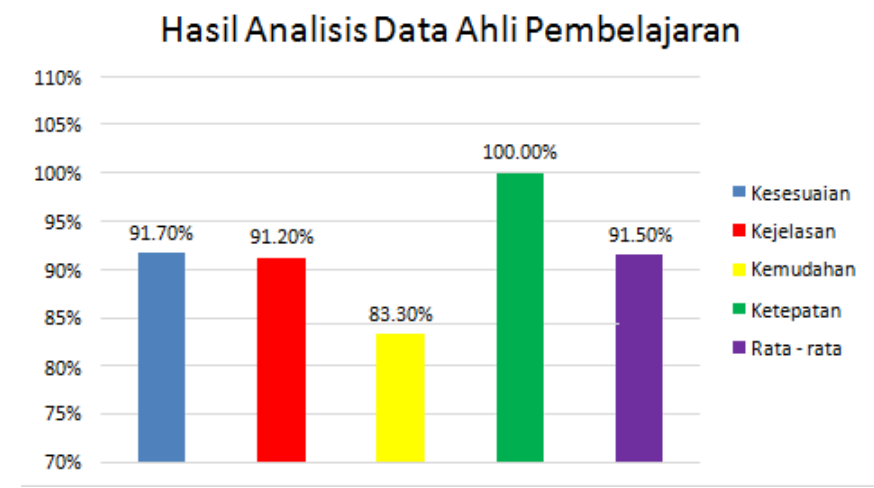

Gambar 2. Diagram Persentase Penilaian Ahli Pembelajaran pada Produk Pengembangan Media Pembelajaran Aplikasi Variasi Permainan Senam lantai

Berdasarkan hasil analisis data yang diperoleh dari ahli pembelajaran dengan persentase sebesar $91.50 \%$, hasil tersebut didapatkan berdasarkan aspek- aspek tertentu kemudian dikonversikan berdasarakan tabel klasifikasi kelayakan menunjukan bahwa produk pengembangan media pembelajaran variasi permainansenam lantai telah memenuhi kriteria sangat valid dan layak digunakan.

Tabel 5. Hasil Analisis Data Ahli Permainan

\begin{tabular}{clcl}
\hline No & \multicolumn{1}{c}{ Aspek } & Kelayakan & Kategori \\
\hline 1 & Kesesuaian & $95.45 \%$ & Sangat Valid \\
2 & Kemampuan & $96.43 \%$ & Sangat Valid \\
3 & Kejelasan & $93.75 \%$ & Sangat Valid \\
4 & Kemenarikan & $100 \%$ & Sangat Valid \\
& Rata-rata & $96.41 \%$ & Sangat Valid \\
\hline
\end{tabular}




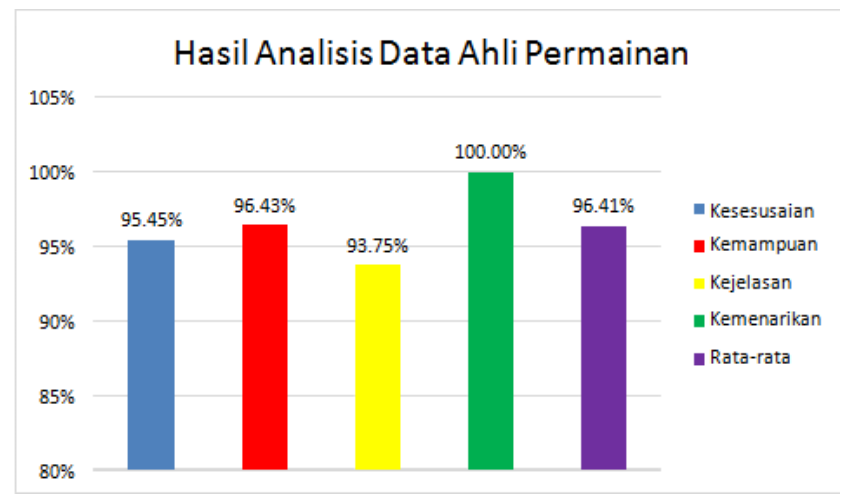

\section{Gambar 3. Diagram Persentase Penilaian Ahli Permainan pada Produk Pengembangan Media Pembelajaran Aplikasi Variasi Permainan Senam Lantai}

Berdasarkan hasil analisis data yang diperoleh dari ahli permainan denganpersentase sebesar 96.41\%, hasil tersebut didapatkan berdasarkan aspek-aspek tertentu kemudian dikonversikan berdasarakan tabel klasifikasi kelayakan menunjukan bahwa produk pengembangan media pembelajaran variasi permainansenam lantai telah memenuhi kriteria sangat valid dan layak digunakan.

Tabel 6. Hasil Analisis Data Ahli Media

\begin{tabular}{clcc}
\hline No & \multicolumn{1}{c}{ Aspek } & Kelayakan & Kategori \\
\hline 1 & Ketepatan & $85.42 \%$ & Sangat Valid \\
2 & Kemenarikan & $89.29 \%$ & Sangat Valid \\
3 & Kesesuaian & $88.16 \%$ & Sangat Valid \\
4 & Kemudahan & $100 \%$ & Sangat Valid \\
& Rata-rata & $90.72 \%$ & Sangat Valid \\
\hline
\end{tabular}

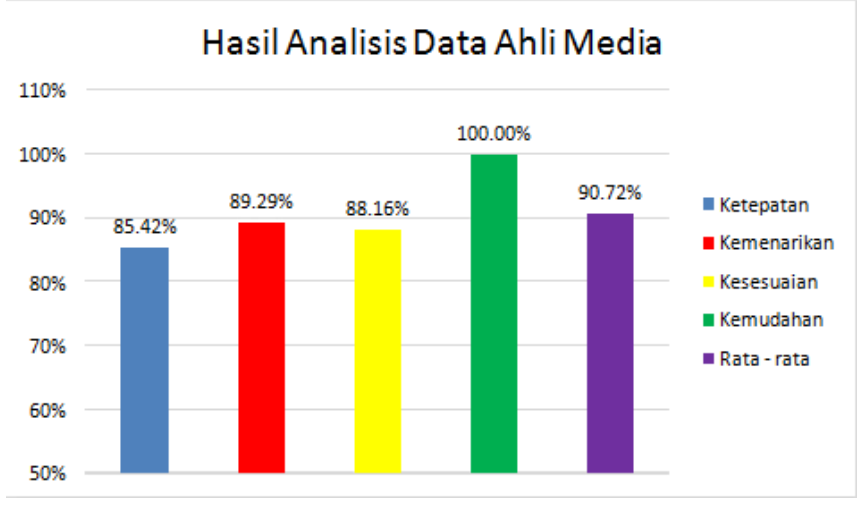

Gambar 4. Diagram Persentase Penilaian Ahli Media pada Produk Pengembangan Media Pembelajara Aplikasi Variasi Permainan Senam Lantai

Berdasarkan hasil analisis data yang diperoleh dari ahli media dengan persentase sebesar 90.72\%, hasil tersebut didapatkan berdasarkan aspek-aspek tertentu kemudian dikonversikan berdasarakan tabel klasifikasi kelayakan menunjukan bahwa produk pengembangan media pembelajaran variasi permainansenam lantai telah memenuhi kriteria sangat valid dan layak digunakan. 
Sport Science and Health, 3(6), 2021, 369-380

Tabel 7. Hasil Analisis Data Ahli Senam Lantai

\begin{tabular}{clcc}
\hline No & \multicolumn{1}{c}{ Aspek } & Kelayakan & Kategori \\
\hline 1 & Ketepatan & $75 \%$ & Cukup Valid \\
2 & Kejelasan & $75 \%$ & Cukup Valid \\
3 & Kemenarikan & $75 \%$ & Cukup Valid \\
& Rata-rata & $75 \%$ & Cukup Valid \\
\hline
\end{tabular}

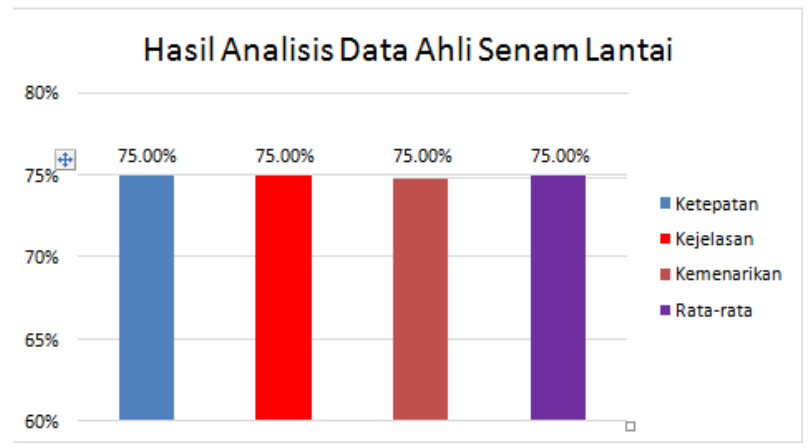

Gambar 5. Diagram Persentase Penilaian Ahli Senam Lantai pada Produk Pengembangan Media Pembelajaran Aplikasi Variasi Permainan Senam lantai

Berdasarkan hasil analisis data yang diperoleh dari ahli PJOK dengan persentase sebesar $75 \%$, hasil tersebut didapatkan berdasarkan aspek-aspek tertentu kemudian dikonversikan berdasarakan tabel klasifikasi kelayakan menunjukan bahwa produk pengembangan media pembelajaran variasi permainansenam lantai telah memenuhi kriteria cukup valid dan layak digunakan.

Tabel 8. Hasil Analisis Uji Coba Kelompok Kecil

\begin{tabular}{clcc}
\hline No & \multicolumn{1}{c}{ Aspek } & Kelayakan & Kategori \\
\hline 1 & Kemenarikan & $81.63 \%$ & Sangat Valid \\
2 & Ketepatan & $94.28 \%$ & Sangat Valid \\
3 & Kesesuaian & $96.19 \%$ & Sangat Valid \\
4 & Kejelasan & $100 . \%$ & Sangat Valid \\
5 & Kemudahan & $85.70 \%$ & Sangat Valid \\
& Rata-rata & $91.56 \%$ & Sangat Valid \\
\hline
\end{tabular}

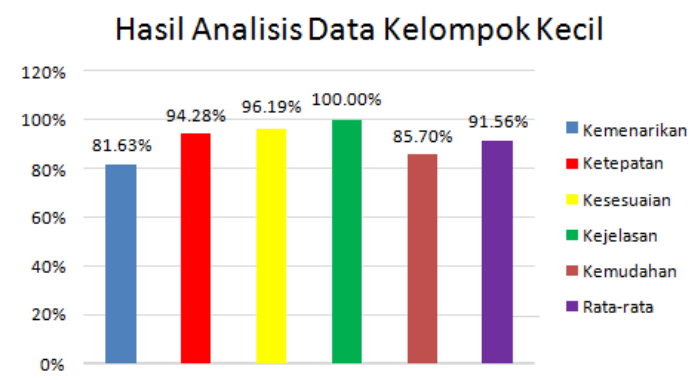

Gambar 6. Diagram Persentase Hasil Analisis Data Uji Coba Kelompok Kecil pada Produk Pengembangan Media Pembelajaran Aplikasi Variasi Permainan Senam lantai 
Berdasarkan hasil analisis data yang diperoleh dari uji coba kelompok kecil kelas IV dengan persentase sebesar $91.56 \%$, hasil tersebut didapatkan berdasarkan aspek-aspek tertentu kemudian dikonversikan berdasarakan tabel klasifikasi kelayakan menunjukan bahwa produk pengembangan media pembelajaran variasi permainan senam lantai telah memenuhi kriteria sangat validdan layak digunakan.

Tabel 9. Hasil Analisis Uji Coba Kelompok Besar

\begin{tabular}{clcc}
\hline No & \multicolumn{1}{c}{ Aspek } & Kelayakan & Kategori \\
\hline 1 & Kemenarikan & $100 \%$ & Sangat Valid \\
2 & Ketepatan & $100 \%$ & Sangat Valid \\
3 & Kesesuaian & $98.60 \%$ & Sangat Valid \\
4 & Kejelasan & $100 \%$ & Sangat Valid \\
5 & Kemudahan & $86.10 \%$ & Sangat Valid \\
& Rata-rata & $96.94 \%$ & Sangat Valid \\
\hline
\end{tabular}

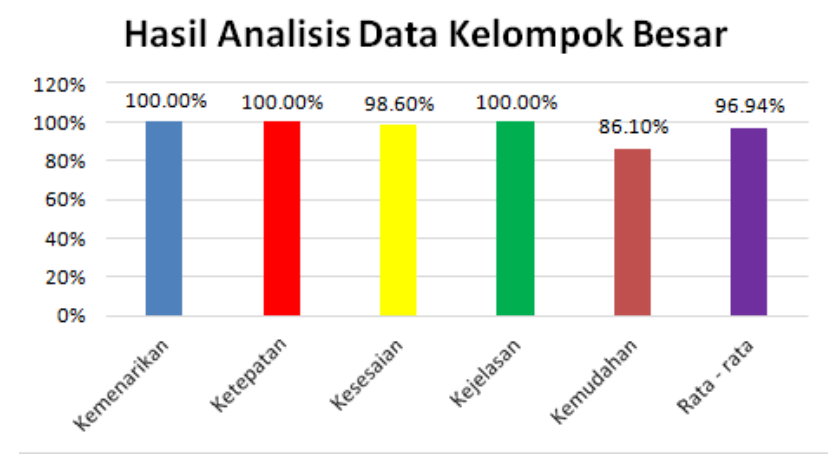

\section{Gambar 7. Diagram Persentase Hasil Analisis Data Uji Coba Kelompok Besar pada Produk Pengembangan Media Pembelajaran Aplikasi Variasi Permainan Senam Lantai}

Berdasarkan hasil analisis data yang diperoleh dari uji coba kelompok kecil kelas IV dengan persentase sebesar $96.94 \%$, hasil tersebut didapatkan berdasarkan aspek-aspek tertentu kemudian dikonversikan berdasarakan tabel klasifikasi kelayakan menunjukan bahwa produk pengembangan media pembelajaran variasi permainan senam lantai telah memenuhi kriteria sangat validdan layak digunakan.

\subsection{Pembahasan}

Produk akhir penelitian ini berupa media pembelajaran variasi permainan senam lantai untuk sekolah dasar kelas IV di Kecamatan Wagir Kabupaten Malang yang menggunakan aplikasi articulate storyline. Pengembanagn media pembelajaran yang tepat dan menarik sangat dibutuhkan. Media pembelajaran adalah segala sesuatu yang digunakan untuk menyalurkan pesan dan dapat merangsang pikiran, perasaan, perhatian dan kemauan siswa sehingga dapat mendorong terjadinya proses belajar yang disengaja, memiliki tujuan, dan terkendali (Suryani dkk, 2018). Dengan adanya media pembelajaran maka tujuan pembelajaran akan terlaksana dengan baik, karena siswa terdorong untuk belajar. Hal itu sejalan dengan pernyataan Darnawati, dkk (2019), dalam jurnalnya menyatakan bahwa software articulate storyline adalah perangkat lunak yang diciptakan untuk memberikan kemudahan dalam menyampaikan materi pembelajaran sebagai media pembelajaran guru kepada peserta didik, aplikasi ini memiliki kemampuan untuk menggabungkan slide, flash 
(swf), video dan karakter animasi menjadi satu dalam aplikasi. Hasil penelitian Listyawati (2013), dalam jurnalnya menyatakan media pembelajaran yang didesain secara menarik dan kreatif memberikan kemudahan pendidik untuk bisa menyampaikan materi yang mudah dipahami peserta didik serta mempengaruhi kemampuan minat belajar peserta didik. Media menjadi sarana alternatif yang dapat digunakan guru untuk memudahkan penyampaian ilmu pengetahuan kepada peserta didik.

Pendapat lainnya mengatakan bahwa sesuatu dikatakan sebagai media pembelajaran apabila media tersebut digunakan untuk menyampaikan pesan dengan tujuan-tujuan pendidikan dan pembelajaran (Dwiyogo, 2010). Media pembelajaran digunakan sebagai sarana penyalur pesan atau materi. Media yang dikembangkan oleh peneliti berupa aplikasi articulate storyline yaitu perangkat lunak (software) yang dipakai sebagai alat untuk berkomunikasi atau media untuk presentasi dengan membuat template sendiri atau membuat presentasi dengan template yang sudah tersedia serta terdapat karakter yang dapat disesuaikan dengan selera masing-masing (Chotimah 2018). Dengan adanya media pembelajaran yang tepat dan menarik, dan juga macam-macam permainan yang disediakan di dalam aplikasi maka sesuailah dengan karakteristik anak usia SD menurut (Burhaein 2017) yaitu anak usia SD senang bermain, senang beraktivitas kelompok, senang bergerak, dan senang praktik langsung. Maka dari itu di dalam aplikasi juga dimuat macam-macam permainan agar pembelajaran semakin menarik dan semangat belajar siswa menjadi meningkat. Permainan merupakan cara utama agar anak terlibat aktif dengan lingkungannya untuk belajar dan berpikir (Morrison, 2012).

Media pada dasarnya adalah perantara informasi pada pengirim dan penerima informasi, terkait pada pembelajaran maka media pembelajaran adalah cara untuk dapat dipakai dalam penyampaian informasi antara pengirim dan penerima pesan biar mempengaruhi perasaan, pemahaman serta kepedulian peserta didik untuk mencapai tujuan pendidikan. Yasin \& Ducha (2017), Articulate storyline merupakan salah satu multimedia interaktif yang dapat digunakan sebagai media pembelajaran interaktif, dalam aplikasi articulate storyline menyediakan berbagai macam template yang bisa dipilih untuk materi ajar yang sepenuhnya disajikan secara interaktif, imersif dan menarik, konten yang ada dalam proses pembuatanya yaitu berbentuk slide powerpoint.

Hasil penelitian sebelumnya Arwanda, Irianto \& Andriani (2020), dalam jurnalnya menunjukan bahwa pengembangan pembelajaran menggunakan articulate storyline untuk kelas IV memberikan pengaruh yang sangat baik terhadap motivasi dan minat belajar siswa, guru memberikan respon sangat baik terhadap pengembangan tersebut dikarenakan menjadi referensi dan membantu guru dalam menyampaikan pembelajaran yang lebih menarik dan kreatif. Sehingga articulate storyline ini adalah salah satu dari beberapa media pembelajaran yang dapat digunakan, ini memberi pengaruh yang positif kepada peserta didik di saat pembelajaran online dan offline. Karena bentuk akhir dari produk ini adalah aplikasi yang dapat dioperasikan melalui smartphone, laptop dan web sehingga memberikan kemudahan kepada pengajar serta peserta didik dalam pelaksanaan pembelajaran. Aplikasi Articulate Storyline menawarkan beberapa template yang cukup menarik sehingga dapat dipersingkat waktu pembuatan terutama untuk membuat soal latihan maupun soal tes. Tampilan yang sederhana akan mempermudah guru dalam mengoperasikannya. Articulate Storyline termasuk dalam multimedia interaktif. Multimedia is a combination of various media (file format) in the form of text, graphics, audio, and interaction and is used to convey messages / information from 
the sender to the recipient of the message / information (Kurniawan, 2019). Yang artinya multimedia adalah kombinasi dari berbagai media (format file) dalam bentuk teks, grafik, audio, dan interaksi dan digunakan untuk menyampaikan pesan / informasi dari pengirim kepada penerima pesan / informasi.

Dalam aplikasi articulate storyline ini nantinya memuat variasi permainan senam lantai kelas IV, bahan ajar senam lantai yang meliputi: pengertian senam lantai, sarana dan prasarana, teknik dasar senam lantai, serta terdapat video pelaksanaan variasi permainan senam lantai, materi senam lantai dan juga terdapat evaluasi penilaian kognitif untuk kelas IV, serta biodata peneliti. Perangkat pembelajaran yang dikembangkan dapat memberikan hal baru dalam kegiatan pembelajaran. Hasil penelitian sebelumnya Akbar \& Hariyanto (2020), dalam jurnalnya menunjukan bahwa pengembangan yang dilakukan dalam media pembelajaran yang disampaikan ke siswa melalui media interaktif memberikan peningkatan motivasi, minat, serta hasil belajar siswa yang baik dalam proses pembelajaran. Hasil temuan lain juga menunjukan bahwa pengembangan media interaktif yang diciptakan dalam pembelajaran dapat menjadi salah satu cara menumbuhkan semangat belajar serta menjadi referensi sumber belajar tambahan mata pelajaran PJOK (Rahman, Kurniawan \& Heynoek, 2020).

Produk pengembangan ini lebih ditekankan pada materi senam lantai untuk kelas IV yang telah dikemas lebih menarik dalam aplikasi articulate storyline dan dapat diakses melalui smartphone, link serta laptop. Dalam video pembelajaran sendiri telah memenuhi gerakan manipulatif yang harus diberikan kepada siswa dalam pembelajaran seperti: gerakan lokomotor, non-lokomotor dan manipulatif dalam senam lantai. Produk ini dapat dijadikan bahan ajar di kelas sebagai pembelajaran pendahuluan untuk memasuki materi baru yaitu senam lantai sebelum dipraktikkan pada kegiatan pembelajaran di lapangan.

Diharapkan setelah di kembangkannya produk ini pembelajaran senam lantai akan dapat lebih bervariasi dan lebih modern, sehingga memberikan pengaruh motivasi minat peserta didik serta menambah pengetahuan guru dalam bidang teknologi yang bermanfaat untuk pengajar dalam pelaksanaan pembelajaran pendidikan jasmani dan kesehatan terutama pembelajaran senam lantai kelas IV.

\section{Simpulan}

Maka dari penelitian dan pengembangan ini mendapatkan suatu kesimpulan bahwa produk pengembangan media pembelajaran variasi permainan senam lantai berbasis aplikasi articulate storyline yang telah dikembangkan peneliti yang memuat materi senam lantai, video variasi permainan senam lantai, dan soal evaluasi dapat layak digunakan dalam pembelajaran PJOK pada tingkat sekolah dasar kelas IV. Dengan Produk ini nantinya dapat memberi kelancaran guru untuk mengantarkan materi senam lantai kepada peserta didik secara up to date.

\section{Daftar Rujukan}

Akbar, R. A., \& Hariyanto, E. (2020). Pengembangan Bahan Ajar Pencak silat Untuk Siswa Sekolah Dasar. Sport Science and Health, 2(7), 350-356. http://journal2.um.ac.id/index.php/jfik/index

Arwanda, P., Irianto, S., \& Andriani, A. (2020). Pengembangan Media Pembelajaran Articulate Storyline Kurikulum 2013 Berbasis Kompetensi Peserta Didik Abad 21 Tema 7 Kelas Iv Sekolah Dasar. AlMadrasah: Jurnal Pendidikan Madrasah Ibtidaiyah, 4(2), 193. https://doi.org/10.35931/am.v4i2.331 
Bangun, S. Y. (2016). Peran Pendidikan Jasmani Dan Olahraga PadaLembaga Pendidikandi Indonesia. Publikasi Pendidikan, 6(3).

Burhaein, E. (2017). Aktivitas Fisik Olahraga Untuk Pertumbuhan Dan Perkembangan Siswa SD. Indonesian Journal of Primary Education, 1(1), 51-58.

Chotimah, U. (2018). Pengembangan Multimedia Interaktif Berbasis Articulate Storyline Untuk Meningkatkan Motivasi Belajar Siswa Pada Mata Pelajaran PKN Kelas XI di SMA Srijaya Negara Palembang. Bhineka Tunggal Ika: Kajian Teori dan Praktik Pendidikan PKn, 5(1), 52-65.

Darnawati, J, Batia, L., Irawaty, \& Salim. (2019). Pemberdayaan Guru Melalui Pengembangan Multimedia Pembelajaran Interaktif dengan Aplikasi Articulate Storyline. Jurnal Pengabdian Kepada Masyarakat, $1(1)$.

Dwiyogo, W. D. (2010). Dimensi Teknologi Pembelajaran Pendidikan Jasmani \& Olahraga. Malang: Wineka Media.

Irawan, D., \& Japarianto, E. (2013). Analisa Pengaruh Kualitas Produk Terhadap Loyalitas Melalui Kepuasan Sebagai Variabel Intervening Pada Pelanggan Restoran Por Kee Surabaya. Jurnal Manajemen Pemasaran.

Kurniawan, A. W. (2019). Multimedia-Based Learning Model for Gymnastics Skills. 7(Icssh 2018), 33-36. https://doi.org/10.2991/icssh-18.2019.8

Lee, W. W., \& Owens, D. L. (2004). Multimedia-Based Instructional Design: Computer-Based Training, Web-Based Training, Distance Broadcast Training, Performance-Based Solutions. John Wiley \& Sons. San Fransisco: Pfeiffer.

Listyawati, M. (2013). Pengembangan Perangkat Pemebelajaran Ipa Terpadu Di SMP. Journal of Innovative Science Education, 1(1).

Morrison, S. (2012). Dasar-Dasar Penidikan Anak Usia Dini (PAUD). Jakarta: PT Index.

Pratama, R. A. (2018). Media Pembelajaran Berbasis Articulate Storyline 2 PadaMateri Menggambar Grafik Fungsi Di Smp Patra Dharma 2 Balikpapan Learning Media Based On Articulate Storyline 2 On Drawing Function Graphs Lesson In Smp Patra Dharma 2 Balikpapan Pendahuluan Matemati.Dimensi, 7(1), 1935.

Rahman, Z., Kurniawan, A. W., \& Heynoek, F. P. (2020). Pengembangan Pembelajaran Kebugaran Jasmani Unsur Kecepatan Berbasis Multimedia Interaktif. Sport Science and Health, 2(1), 78-92. http://journal2.um.ac.id/index.php/jfik/article/view/11692/5123

Sudirjo, E., \& Alif, M. N. 2019. Pertumbuhan dan Perkembangan Motorik. Sumedang: UPI Sumedang Press

Sugiyono. (2015). Metode Penelitian Pendidikan. Bandung: Alfabeta.

Suryani. (2018). Media Pembelajaran Inovatif dan Pengembangannya. Bandung: PT Remaja Rosdakarya Offset.

Tatminingsih, S. (2019). Kemampuan Sosial Emosional Anak Usia Dini di Nusa Tenggara Barat. Jurnal Obsesi: Jurnal Pendidikan Anak Usia Dini, 3(2), 484-493.

Yasin, A. N., \& Ducha, N. (2017). Kelayakan Teoritis Multimedia Interaktif Berbasis Articulate Storyline Materi Sistem Reproduksi Manusia Kelas Xi SMA. BioEdu, 6(2), 571-579. 